\title{
Changes in endogenous tissue glutathione level in relation to murine ascites tumor growth and the anticancer activity of cisplatin
}

D. Khynriam and S.B. Prasad
Cell and Tumor Biology Laboratory, Department of Zoology,

School of Life Sciences, North-Eastern Hill University, Shillong, India
Correspondence

S.B. Prasad

Department of Zoology

School of Life Sciences

North-Eastern Hill University

Shillong 793022

India

Fax: +91-364-55-0076/55-0108

E-mail: sbpnehu@hotmail.com

or sbprasad@nehu.ac.in

Research supported by the University Grants Commission, New Delhi (COSIST, DRS program) and by North-Eastern Hill University, Shillong, India.

Received December 10, 2001 Accepted September 13, 2002

\begin{abstract}
Changes in glutathione levels were determined in tissues of 11- to 12week-old Swiss albino mice at different stages of Dalton's lymphoma tumor growth and following cisplatin $(8 \mathrm{mg} / \mathrm{kg}$ body weight, ip) treatment for 24-96 h, keeping 4-5 animals in each experimental group. Glutathione levels increased in spleen of tumor-bearing compared to normal mice $(9.95 \pm 0.14 v s 7.86 \pm 1.64 \mu \mathrm{mol} / \mathrm{g}$ wet weight, $\mathrm{P} \leq 0.05)$ but decreased in blood $(0.64 \pm 0.10$ vs $0.85 \pm 0.09 \mathrm{mg} / \mathrm{ml})$ and testes $(9.28 \pm 0.15$ vs $10.16 \pm 0.28 \mu \mathrm{mol} / \mathrm{g}$ wet weight, $\mathrm{P} \leq 0.05)$. Dalton's lymphoma cells showed an increase in glutathione concentration (4.43 $\pm 0.26 \mu \mathrm{mol} / \mathrm{g}$ wet weight) as compared to splenocytes, their normal counterpart $(3.62 \pm 0.41 \mu \mathrm{mol} / \mathrm{g}$ wet weight). With the progression of tumor in mice, glutathione levels decreased significantly in testes $(\sim 10 \%)$ and bone marrow cells $(\sim 13 \%)$ while they increased in Dalton's lymphoma cells (28-46\%) and spleen (15-27\%). Glutathione levels in kidney, Dalton's lymphoma cells and bone marrow cells $(8.50 \pm 1.22,4.43 \pm 0.26$ and $3.28 \pm 0.17 \mu \mathrm{mol} / \mathrm{g}$ wet weight, respectively) decreased significantly $(6.04 \pm 0.42,3.51 \pm 0.32$ and $2.17 \pm 0.14 \mu \mathrm{mol} / \mathrm{g}$ wet weight, $\mathrm{P} \leq 0.05$ ) after in vivo cisplatin treatment for $24 \mathrm{~h}$. Along with a decrease in glutathione level, the glutathione-S-transferase (GST) activity also decreased by $60 \%$ in tumor cells after cisplatin treatment. The elevated drug uptake by the tumor cells under the conditions of reduced glutathione concentration and GST activity after treatment could be an important contributory factor to cisplatin's anticancer activity leading to tumor regression. Furthermore, lower doses of cisplatin in combination with buthionine sulfoximine (an inhibitor of glutathione synthesis) may be useful in cancer chemotherapy with decreased toxicity in the host.
\end{abstract}

\section{Introduction}

Cis-diamminedichloroplatinum(II), commonly known as cisplatin, is a widely used anticancer drug against several animal $(1,2)$ and human malignancies (3). Many of its
Key words - Cisplatin

- Dalton's lymphoma

- Glutathione

- Glutathione-S-transferase

- Chemotherapy biological properties and effects have been well documented $(1,4)$. It has been suggested that cisplatin exerts its anticancer activity by reacting with cellular DNA (1). In addition to reacting with DNA, cisplatin affects the host immune response (5), cell surface (6), 
tissue calcium and potassium concentrations (7), various enzymes such as 5'-nucleotidase, arginase, cathepsins and lactate dehydrogenase (8), and mitochondria (9), properties that have led to the proposal of the involvement of cisplatin in multistep and multilevel actions on the tumor cell/host relationship during cisplatin-mediated chemotherapy $(8,9)$. However, the therapeutic efficacy of the drug is limited due to various dose-limiting side effects mainly involving nephrotoxicity (10), hematotoxicity (11), mutagenicity $(12,13)$ and the development of acquired resistance (14). The changes in glutathione levels have been shown to be of importance in the occurrence of these side effects (11-15). L-buthionine-(S,R)-sulfoximine (BSO) is an inhibitor of $\gamma$-glutamylcysteine synthetase and has often been used to deplete cellular reduced glutathione (16). In vitro studies have demonstrated that cancer cells resistant to alkylating agents including cisplatin can be made sensitive to these drugs through BSO-induced glutathione depletion (17).

Glutathione, an endogenous intracellular thiol-containing tripeptide (L- $\gamma$-glutamyl-Lcysteinyl-glycine), is an important antioxidant and has been the focus of interest in cancer chemotherapy (18). Under normal physiological conditions mammalian cells maintain more than $98 \%$ of glutathione in the reduced form (GSH) at intracellular concentration of 0.5 to $10 \mathrm{mM}$ (19). GSH plays a crucial role in numerous biochemical processes including diverse bioreductive reactions, transport, protection against harmful free radicals and xenobiotics, and detoxification of metals and electrophiles (19). GSH has been implicated in the metabolism of cisplatin (20) and other metals causing alterations in the rate of metal uptake and elimination. The reactive thiol group of GSH is also responsible for many other functions, i.e., i) maintenance of protein structure and function by reducing the disulfide linkages of proteins, ii) regulation of protein synthesis and degradation, iii) maintenance of im- mune function, iv) leukotriene and prostaglandin metabolism, v) modulation of microtubule-related processes, vi) bile formation, and vii) DNA synthesis (19).

Therefore, it was of interest to determine GSH levels in various tissues during ascites Dalton's lymphoma growth in vivo and cisplatin treatment. Platinum uptake and glutathione-S-transferase (GST; EC 2.5.1.18) activity were also measured in Dalton's lymphoma cells collected from mice under different experimental conditions in an attempt to identify the mechanism of GSH changes and its significance in cisplatin-mediated cancer chemotherapy.

\section{Material and Methods}

\section{Chemicals}

GSH, BSO, 5,5'-dithiobis-2-nitrobenzoic acid (DTNB), and 1-chloro-2,4-dinitrobenzene (CDNB) were purchased from Sigma (St. Louis, MO, USA). Cisplatin was obtained from Biochem Pharmaceutical Industries, Mumbai, India. Other chemicals used in the experiments were of analytical grade. The solutions were prepared in twice glassdistilled water.

\section{Tumor maintenance}

Inbred Swiss albino mice were maintained in the laboratory with free access to commercially available food pellets and water. For each experimental determination, 45 mice aged 10-12 weeks were used. Ascites Dalton's lymphoma tumor was maintained in vivo by intraperitoneal (ip) transplantation of $1 \times 10^{7}$ tumor cells per animal ( 0.25 volume, in phosphate-buffered saline, $\mathrm{PBS}$ ). PBS was prepared by adding $0.15 \mathrm{M} \mathrm{NaCl}$ to $0.01 \mathrm{M}$ sodium phosphate buffer, $\mathrm{pH}$ 7.4. Since tumor-transplanted animals usually survived for 18-20 days, days 5, 10 and 15 were considered to be the initial, middle and later stages of tumor growth, respectively. 


\section{Cisplatin treatment and tissue collection}

On the 5th, 10th and 15th day of tumor growth, tumor-bearing mice were killed by cervical dislocation, and liver, kidney, spleen, blood, ascites tumor, testes, humerus and femur bones were collected. Bone marrow cells were prepared from humerus and femur by flushing in PBS with a hypodermic syringe and by centrifugation $(3000 \mathrm{~g}, 10 \mathrm{~min})$ to collect the bone marrow cell pellet. Ascites tumor was also centrifuged $(3000 \mathrm{~g}, 10$ min) to separate the Dalton's lymphoma cell pellet and the ascites supernatant. According to the dose and treatment schedule used earlier by us (11), a single dose of cisplatin ( $8 \mathrm{mg} / \mathrm{kg}$ body weight, ip) was administered to tumor-bearing mice on the 10th day posttumor transplantation and after 24, 48, 72 and $96 \mathrm{~h}$ of treatment tissues were collected and used for GSH determinations. GSH was also determined in the same tissues of control (untreated tumor-bearing mice injected with normal saline only) and normal (untreated, non-tumor-bearing) mice. Splenocytes were prepared from the spleens of normal mice as described earlier (6) and used as the normal counterpart of Dalton's lymphoma cells in GSH determinations.

\section{Blood glutathione}

Blood GSH was determined by the method of Beutler et al. (21). Virtually all non-protein sulfhydryl of red blood cells is in the form of GSH. DTNB is a disulfide compound which is readily reduced by sulfhydryl compounds forming a highly colored yellow anion.

Briefly, $0.9 \mathrm{ml}$ water and $1.5 \mathrm{ml}$ precipitating solution (1.67 g glacial metaphosphoric acid, $0.20 \mathrm{~g} \mathrm{Na}_{2}$ EDTA, $30 \mathrm{~g} \mathrm{NaCl}, 100 \mathrm{ml}$ water) were added immediately to $100 \mu \mathrm{l}$ of blood and mixed well. After 5 min of incubation at room temperature the reaction mixture was centrifuged $\left(3000 \mathrm{~g}\right.$ at $\left.4^{\circ} \mathrm{C}, 15 \mathrm{~min}\right)$ and $2.0 \mathrm{ml}$ of $0.3 \mathrm{~mol} / 1$ phosphate solution and $250 \mu \mathrm{l}$ DTNB solution (200 $\mathrm{mg}$ in 100 $\mathrm{ml}$ of $1 \%$ sodium citrate solution) were added to $500 \mu \mathrm{l}$ of the clear supernatant. A blank was prepared with $1 \mathrm{ml}$ phosphate solution, $1 \mathrm{ml}$ water, $0.5 \mathrm{ml}$ precipitating solution, and $250 \mu 1$ DTNB solution. Both the blank and sample reaction mixtures were read against water at $412 \mathrm{~nm}$ in a Beckman DU-640 spectrophotometer. GSH concentration was calculated on the basis of a millimolar extinction coefficient of 13.6 and a molecular weight of 307.

\section{Glutathione in other tissues}

Total GSH was estimated in various tissues by the method of Sedlak and Lindsay (22). Briefly, 5\% tissue homogenates were prepared in $20 \mathrm{mM}$ EDTA, $\mathrm{pH} 4.7$, and 100 $\mu l$ of the homogenate or pure GSH was added to $0.2 \mathrm{M}$ Tris-EDTA buffer $(1.0 \mathrm{ml}$, $\mathrm{pH}$ 8.2) and $20 \mathrm{mM}$ EDTA, pH $4.7(0.9 \mathrm{ml})$ followed by $20 \mu \mathrm{l}$ of Ellman's reagent (10 $\mathrm{mmol} / \mathrm{l}$ DTNB in methanol). After $30 \mathrm{~min}$ of incubation at room temperature, absorbance was read at $412 \mathrm{~nm}$ in a Beckman DU-640 spectrophotometer. Samples were centrifuged before the absorbance of the supernatants was measured.

\section{Glutathione-S-transferase assay}

GST activity was assayed in Dalton's lymphoma cells of tumor-bearing mice under different experimental conditions. Ascites tumor was centrifuged at $3000 \mathrm{~g}$ at $4^{\circ} \mathrm{C}$ for $10 \mathrm{~min}$ and the tumor cell pellet was collected. A $10 \%$ homogenate of liver and Dalton's lymphoma cells in $0.1 \mathrm{M}$ sodium phosphate-1 $\mathrm{mM} \mathrm{Na}_{2}$ EDTA buffer, $\mathrm{pH} 6.5$, was obtained with a motor-driven Teflonpestle homogenizer at $4^{\circ} \mathrm{C}$. The tissue homogenates were centrifuged at $27,000 \mathrm{~g}$ at $4^{\circ} \mathrm{C}$ for $20 \mathrm{~min}$ and the respective supernatants were collected as the enzyme source.

GST activity was assayed by the method of Habig et al. (23). The reaction mixture of 
$1.0 \mathrm{ml}$ contained $850 \mu \mathrm{l}$ of $0.1 \mathrm{M}$ sodium phosphate-1 mM Na 2 EDTA buffer, $\mathrm{pH} 6.5$, $50 \mu 1$ of $20 \mathrm{mM} \mathrm{GSH}$ in deionized water, and $50 \mu \mathrm{l}$ of $20 \mathrm{mM}$ CDNB in $95 \%$ ethanol. The reaction mixture, maintained at $30^{\circ} \mathrm{C}$, was started by adding $50 \mu \mathrm{l}$ enzyme and the increase in absorbance at $340 \mathrm{~nm}$ was monitored for 3 min with a Beckman DU-640 spectrophotometer. The enzyme activity was calculated using the extinction coefficient $\left(E_{340}=9.6 \mathrm{mM}^{-1} \mathrm{~cm}^{-1}\right)$. One unit of enzyme activity was defined as the amount of enzyme that catalyzed the conjugation of 1 $\mu$ mol CDNB per minute.

The same supernatants used for enzyme assays were also used for protein determination by the method of Lowry et al. (24) using bovine serum albumin as standard. The specific activity of the enzyme is reported per mg protein.

\section{Buthionine sulfoximine and cisplatin treatment}

To standardize the time of maximum BSO-induced depletion, BSO at the dose of $5 \mathrm{mM} / \mathrm{kg}$ body weight (11) was injected ip into a group of mice on the 10th day posttumor transplantation. Different tissues were then collected and used for GSH determinations at 2-h intervals after treatment. Since the maximum GSH depletion (43-45\%) induced by BSO in Dalton's lymphoma cells was observed $8 \mathrm{~h}$ after treatment, in the experiments involving BSO plus cisplatin treatments $\mathrm{BSO}$ was given $8 \mathrm{~h}$ prior to cisplatin treatment.

\section{Determination of platinum uptake by Dalton's lymphoma cells}

The Dalton's lymphoma cell pellet used for GSH estimation was also processed for platinum uptake analysis. The pellet $(0.5 \mathrm{~g})$ was digested with $5.0 \mathrm{ml}$ nitric acid and a few drops of hydrogen peroxide in a clean conical flask with gentle heating to near dryness. Perchloric acid $(5.0 \mathrm{ml})$ was added to the digests and again heated to near dryness to remove excess nitric acid. This last stage was repeated until a clear solution resulted. The digests were finally dissolved in $5 \mathrm{ml}$ of $5 \%$ nitric acid (distilled water and nitric acid at the ratio of 95:5 $\mathrm{ml}$ ), and the filtrate was stored in polypropylene bottles for platinum analysis using a plasma lab ICP-OES emission spectrometer operated at 700 volts PMT and $214,438 \mathrm{~nm}$ wavelength after calibrating the instrument with the appropriate standard solutions.

\section{Macrophage-Dalton's lymphoma cell interactions in vitro}

Peritoneal exudate cells (PEC) from normal mice were harvested as described by Dileepan et al. (25). Four days prior to PEC collection, mice were injected $i p$ with $2 \mathrm{ml}$ of $4 \%$ thioglycolate and cells were collected by lavage of the peritoneal cavity with $5 \mathrm{ml}$ serum-free 199 medium containing 100 $\mathrm{U} / \mathrm{ml}$ penicillin. PEC were centrifuged at $400 \mathrm{~g}$ for $10 \mathrm{~min}$ and washed twice with 199 medium. The cells were resuspended in complete 199 medium supplemented with $10 \%$ fetal bovine serum at a concentration of $1 \mathrm{x}$ $10^{5} / \mathrm{ml}$ on a $24-w e l l$ culture dish (Genetix, New Delhi, India) and incubated at $37^{\circ} \mathrm{C}$ in an incubator in the presence of $5 \% \mathrm{CO}_{2}-95 \%$ air. After $2 \mathrm{~h}$, the culture plates were shaken and washed with warm medium $\left(37^{\circ} \mathrm{C}\right)$ to remove non-adherent cells. Fresh medium was added and the mixture was incubated overnight. Different groups of tumor-bearing mice were treated with cisplatin (4 and 8 $\mathrm{mg} / \mathrm{kg}$ body weight) and with BSO ( $8 \mathrm{~h}$ prior to cisplatin treatment) plus cisplatin. Twentyfour hours after cisplatin treatment, Dalton's lymphoma cells were aspirated from the peritoneal cavity, washed with 199 medium, resuspended in complete medium at a concentration of $1 \times 10^{4}$ cells $/ \mathrm{ml}$ and used as target cells for macrophages.

A macrophage monolayer was washed 
with warm medium and target Dalton's lymphoma cells (treated and control) were added at an effector:target ratio of 10:1 and further incubated for $24 \mathrm{~h}$. After incubation, the supernatants were discarded, fresh medium was added and the number of macrophageDalton's lymphoma interacting cells was scored and analyzed under different treatment conditions.

\section{Host survival}

Tumor-transplanted animals were randomly divided into four groups consisting of 10 mice per group. On the 8th day posttumor transplantation, mice in groups I and II received cisplatin at the dose of 4 and 8 $\mathrm{mg} / \mathrm{kg}$ body weight, respectively. Mice in group III were treated with BSO $(5 \mathrm{mM} / \mathrm{kg}$ body weight $8 \mathrm{~h}$ prior to cisplatin treatment) plus cisplatin ( $4 \mathrm{mg} / \mathrm{kg}$ body weight). The mice in group IV received the same volume of normal saline and were used as control. The deaths, if any, of the hosts in different groups were recorded daily and the survival pattern of the hosts was determined for different groups. The antitumor efficacy of the drug in different groups is reported as percent increase in life span calculated as $[(\mathrm{T}-\mathrm{C} / \mathrm{C})] \mathrm{x} 100$, where $\mathrm{T}$ and $\mathrm{C}$ are the mean survival days of treated and untreated control mice, respectively.

\section{Results}

\section{GSH levels during tumor growth and cisplatin treatment}

GSH levels did not change much in liver and kidney at different stages of tumor growth. However, a significant decrease in GSH levels was noted in testes $(\sim 10 \%)$ and bone marrow cells $(\sim 13 \%)$, while an increase was observed in spleen (15-27\%) and Dalton's lymphoma cells (28-46\%) during 5 to 15 days of tumor growth (Figure 1).

Cisplatin treatment of tumor-bearing mice for 24-96 h showed a significant $(\mathrm{P} \leq 0.05)$ decrease of GSH level in kidney (18-29\%), Dalton's lymphoma cells (14-21\%), spleen (12-18\%), bone marrow cells $(20-34 \%)$ (Table 1) and blood (26-37\%) for one or more observation times (Table 2).

Comparison of GSH levels in tissue of normal and tumor-bearing mice revealed an increase in spleen, but a decrease in testes (Table 3) and blood (Table 2) of tumorbearing mice. A 22\% increase in GSH content was observed in Dalton's lymphoma cells as compared to splenocytes which were used as their normal controls (Table 3 ).

\section{Glutathione-S-transferase activity}

GST specific activity (units/mg protein)

\begin{tabular}{lcccccc}
\multicolumn{5}{c}{ Table 1. Changes in total GSH content in the tissues of tumor-bearing mice after cisplatin treatment in vivo. } \\
\hline Treatment & Liver & Kidney & Testes & $\begin{array}{c}\text { Bone marrow } \\
\text { cells }\end{array}$ & $\begin{array}{c}\text { Dalton's } \\
\text { lymphoma cells }\end{array}$ & Spleen \\
\hline Control & $11.91 \pm 1.06$ & $8.50 \pm 1.22$ & $9.28 \pm 0.15$ & $3.28 \pm 0.17$ & $4.43 \pm 0.26$ & $9.95 \pm 0.14$ \\
CP (24 h) & $11.64 \pm 1.88$ & $6.04 \pm 0.42^{*}$ & $9.03 \pm 0.29$ & $2.17 \pm 0.14^{*}$ & $3.51 \pm 0.32^{*}$ & $9.80 \pm 0.14$ \\
CP (48 h) & $11.68 \pm 0.42$ & $6.52 \pm 0.37^{*}$ & $9.08 \pm 0.23$ & $2.20 \pm 0.15^{*}$ & $3.82 \pm 0.21^{*}$ & $8.13 \pm 0.12^{*}$ \\
CP (72 h) & $11.75 \pm 0.13$ & $6.94 \pm 0.22^{*}$ & $9.10 \pm 0.33$ & $2.61 \pm 0.12^{*}$ & $4.02 \pm 0.32$ & $9.10 \pm 0.11$ \\
CP (96 h) & $11.84 \pm 0.15$ & $7.68 \pm 0.33$ & $9.11 \pm 0.39$ & $3.01 \pm 0.26$ & $4.21 \pm 0.45$ & $8.88 \pm 0.17^{*}$
\end{tabular}

$\mathrm{CP}=$ cisplatin, administered ip $(8 \mathrm{mg} / \mathrm{kg}$ body weight $)$ to tumor-bearing mice. Control $=$ tissues from untreated tumor-bearing hosts. Data are reported as $\mu \mathrm{mol} / \mathrm{g}$ wet weight as means $\pm S D(N=3-4)$. * $P \leq 0.05$ compared to the respective control (Student $t$-test). 
Table 2. Changes in blood GSH levels of tumor-bearing mice after cisplatin treatment.

\begin{tabular}{ll}
\hline Treatment & GSH \\
\hline Normal mice & $0.85 \pm 0.09$ \\
Tumor-bearing mice (control) & $0.64 \pm 0.10^{* *}$ \\
Cisplatin $(24 \mathrm{~h})$ & $0.57 \pm 0.02$ \\
Cisplatin $(48 \mathrm{~h})$ & $0.47 \pm 0.06^{*}$ \\
Cisplatin $(72 \mathrm{~h})$ & $0.40 \pm 0.01^{*}$ \\
Cisplatin $(96 \mathrm{~h})$ & $0.42 \pm 0.08^{*}$
\end{tabular}

Normal mice $=$ mice without tumor or treatment. GSH content is reported as $\mathrm{mg} / \mathrm{ml}$. Data are reported as means $\pm S D(N=4-5)$.

${ }^{*} \mathrm{P}<0.05$ compared to control; ${ }^{*} \mathrm{P}<0.05$ compared to normal mice (Student $t$-test).
Table 3. GSH levels in the tissues of normal and tumor-bearing mice on the 10th day following tumor transplantation.

\begin{tabular}{lcc}
\hline Tissue & $\begin{array}{c}\text { GSH (tissues of } \\
\text { normal mice) }\end{array}$ & $\begin{array}{c}\text { GSH (tissues of } \\
\text { tumor-bearing mice) }\end{array}$ \\
\hline Liver & $11.72 \pm 1.50$ & $11.92 \pm 1.06$ \\
Kidney & $8.03 \pm 1.58$ & $8.50 \pm 1.22$ \\
Testes & $10.16 \pm 0.28$ & $9.28 \pm 0.15^{*}$ \\
Spleen & $7.86 \pm 1.64$ & $9.95 \pm 0.14^{*}$ \\
Bone marrow & $3.10 \pm 0.28$ & $3.28 \pm 0.17$ \\
Splenocytes & $3.62 \pm 0.41$ & - \\
Dalton's lymphoma cells & - & $4.43 \pm 0.26^{*}$
\end{tabular}

Splenocytes from normal mice were used as the normal control of Dalton's lymphoma cells. GSH content is reported as $\mu \mathrm{mol} / \mathrm{g}$ wet weight. Data are reported as means $\pm S D(N=4-5)$.

${ }^{*} \mathrm{P}<0.05$ compared to the respective tissue from normal animal (Student $t$-test).

Table 4. Antitumor activity of cisplatin and L-buthionine-(S,R)-sulfoximine (BSO) plus cisplatin against murine ascites Dalton's lymphoma.

\begin{tabular}{lcc}
\hline Treatment & Survival days & I.L.S. (\%) \\
\hline Control & $19.00 \pm 2.5$ & - \\
Cisplatin (4 mg) & $29.25 \pm 3.0^{*}$ & 53.95 \\
Cisplatin 8 mg) & $>60^{*}$ & $>216$ \\
BSO + cisplatin (4 mg) & $42.50 \pm 1.0^{*}$ & 123.68 \\
\hline
\end{tabular}

BSO was administered ip $8 \mathrm{~h}$ prior to cisplatin treatment on the 8th day post-tumor transplantation. I.L.S. $(\%)=$ percent increase in the life span was calculated as described in Methods. Data are reported as means \pm SD (3-4 experimental determinations for 10 mice per group).

${ }^{*} \mathrm{P}<0.05$ compared to control (Student $t$-test). in Dalton's lymphoma cells $(1.28 \pm 0.19)$ decreased to $0.43 \pm 0.05,0.55 \pm 0.04,0.25 \pm$ 0.03 , and $0.26 \pm 0.04$ at $24,48,72$ and $96 \mathrm{~h}$, respectively, of cisplatin treatment, corresponding to a $\sim 60-80 \%$ reduction in GST activity.

\section{BSO treatment}

Treatment of mice with BSO, an inhibitor of GSH synthesis, decreased GSH levels in all tissues, with a gradual recovery at 10$12 \mathrm{~h}$ of treatment. In Dalton's lymphoma cells maximum $(>40 \%)$ depletion in GSH concentration was noted at $8 \mathrm{~h}$ of BSO treatment (Figure 2).

\section{Platinum uptake by Dalton's lymphoma cells}

Platinum uptake by Dalton's lymphoma cells at $8 \mathrm{~h}$ of cisplatin treatment was $3.6 \mu \mathrm{g}$ platinum/g Dalton's lymphoma cells, later decreasing from 24 to $48 \mathrm{~h}$ (Figure 3). However, when cisplatin was given to the mice in combination with $\mathrm{BSO}$, platinum uptake by cells was found to be higher than after cisplatin treatment alone at 8 and $24 \mathrm{~h}$ of treatment (Figure 3), followed by a decrease at 48 $\mathrm{h}$ of treatment.

\section{In vitro macrophage-Dalton's lymphoma cell interactions}

In in vitro studies on macrophageDalton's lymphoma cell interactions, one or two Dalton's lymphoma cells connecting to macrophages through cytoplasmic bridges were counted as interacting cells. These interactions were much lower $(\sim 9 \%)$ in the control and increased significantly $(\mathrm{P} \leq 0.05)$ in cisplatin-treated groups in a dose-dependent manner ( $28-55 \%)$. However, as compared to the mice treated with cisplatin (4 $\mathrm{mg} / \mathrm{kg}$ body weight) alone, combined treatment with BSO plus cisplatin ( $4 \mathrm{mg} / \mathrm{kg}$ body weight $)$ caused a significant $(\mathrm{P} \leq 0.05)$ increase in the interactions of Dalton's lymphoma cells with macrophages. 
Figure 1. Changes in GSH levels in the tissues of mice at different stages of tumor growth in vivo. Results are reported as means $\pm S D(N=4-5)$. ${ }^{*} P \leq 0.05$ compared to day 5 for Dalton's lymphoma cells, and to day 0 for other tissues (Student $t$-test).

\section{Host survival patterns}

Following tumor transplantation, an early sign of tumor development was noted from the 3rd-4th day onwards. Tumor-inoculated animals survived for $19 \pm 2.5$ days. In the group of mice treated with a therapeutic dose of cisplatin ( $8 \mathrm{mg} / \mathrm{kg}$ body weight) about $80 \%$ of the animals survived for more than 60 days and were tumor free. However, comparison of treatment of tumor-bearing mice with a subtherapeutic dose of cisplatin (4 $\mathrm{mg} / \mathrm{kg}$ body weight) alone and its combination with BSO showed that combined treatment with BSO and a subtherapeutic dose of cisplatin resulted in a further increase in survival time up to 40 days (Figure 4). Thus, the percent increase in life span was about $53 \%$ in mice receiving a subtherapeutic dose of cisplatin and doubled to $\sim 123 \%$ after combination chemotherapy with $\mathrm{BSO}$ and a subtherapeutic dose of cisplatin. However, 8 mg cisplatin treatment provided an even longer survival time than BSO plus $4 \mathrm{mg}$ cisplatin (Table 4).

\section{Discussion}

Glutathione, the most abundant thiol in the cell, is maintained in reduced form (GSH) by NADPH-dependent glutathione reductase (19). The present results showed that GSH concentrations differ widely among different tissues in the mouse. The highest concentration, found in the liver, was approximately four times that observed in bone marrow cells which showed the lowest concentration (Figure 1). GSH concentration did not change significantly in liver and kidney during in vivo tumor growth in mice, but
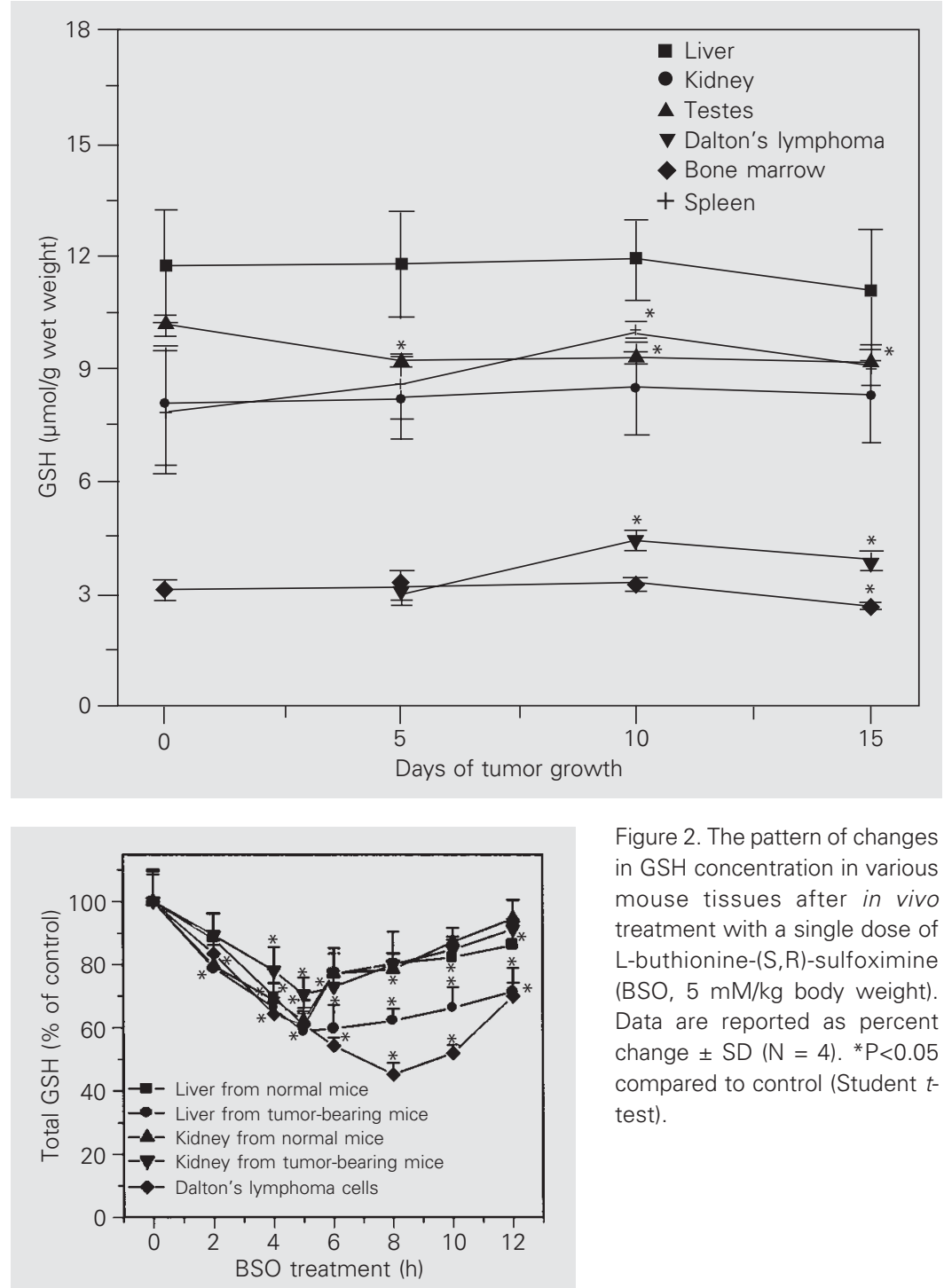

Figure 2. The pattern of changes in GSH concentration in various mouse tissues after in vivo treatment with a single dose of L-buthionine-(S,R)-sulfoximine (BSO, $5 \mathrm{mM} / \mathrm{kg}$ body weight). Data are reported as percent change $\pm S D(N=4) .{ }^{*} P<0.05$ compared to control (Student $t$ test).

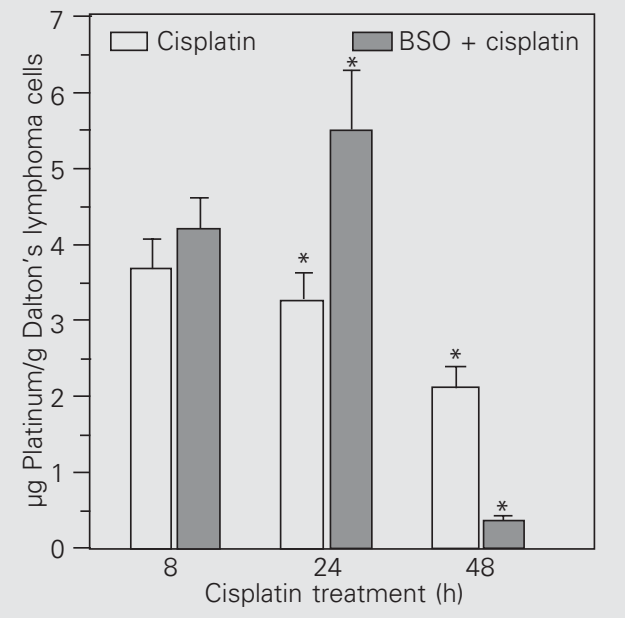

Figure 3. Platinum uptake by Dalton's lymphoma cells after the treatment of tumor-bearing mice with cisplatin $(8 \mathrm{mg} / \mathrm{kg}$ body weight) alone or with Lbuthionine-(S, R)-sulfoximine (BSO). BSO was administered $8 \mathrm{~h}$ prior to cisplatin treatment. Data are reported as means \pm $\mathrm{SD}(N=4) .{ }^{*} P \leq 0.05$ compared to respective $8 \mathrm{~h}$ of treatment (Student $t$-test). 
decreased in testes and bone marrow and increased in spleen and Dalton's lymphoma cells (Figure 1). The observed GSH increase in spleen and Dalton's lymphoma cells was maximum on day 10 of tumor growth, slightly decreasing thereafter over the next 4-5 days when tumor growth was probably reduced. In Ehrlich ascites tumor cells, maximal GSH concentration was observed by about the 7th day of tumor growth, followed by a significant decrease on the 14th day of tumor growth, which was correlated with a decrease in cell proliferation and in the rate of GSH synthesis (26).

Cancer cells can generate large amounts of hydrogen peroxide which may contribute to their ability to mutate and damage normal tissues, and, moreover, facilitate tumor growth and invasion (27). It has been suggested that persistent oxidative stress in tumor cells could partly explain some important characteristics of cancer, such as activated proto-oncogenes, genomic instability, drug resistance, invasion and metastasis (28), and the resistance of many cells against oxidative stress is often associated with high intracellular levels of GSH (29). The observed increase of GSH mainly in tumor cells suggests its involvement in facilitating the proliferation and metabolism of tumor

Figure 4. Mean survival pattern of tumor-bearing mice under different treatment conditions. Control $=$ mice receiving normal saline only. Cisplatin (4 or $8 \mathrm{mg} /$ $\mathrm{kg}$ body weight) was administered ip on the 8th day after tumor transplantation. L-buthionine-(S,R)-sulfoximine (BSO, 5 $\mathrm{mM} / \mathrm{kg}$ body weight) was administered $8 \mathrm{~h}$ prior to cisplatin treatment. Data are reported for 10 mice in each group.

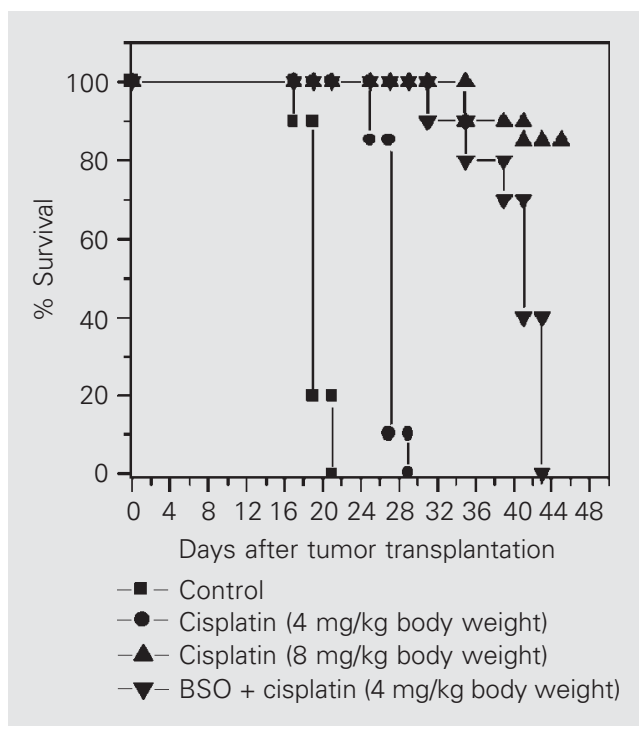

cells in the host and agrees with the report that elevation of intracellular GSH in tumor cells is associated with mitogenic stimulation (30) and that GSH controls the onset of tumor cell proliferation by regulating protein kinase $\mathrm{C}$ activity and intracellular $\mathrm{pH}$ (31). A decrease in the rate of cancer cell proliferation has also been correlated with a decrease in GSH level in tumor cells (26). Thus, the variation of GSH concentration in the Dalton's lymphoma cells and other tissues with tumor growth in the host may reflect alterations in the antioxidant machinery accompanied by changes in the rate of proliferation of Dalton's lymphoma cells in the host.

As compared to liver, kidney and bone marrow of normal animals, GSH levels increased slightly in the respective tissues of tumor-bearing animals (Table 3). However, significant changes were noted in other tissues, i.e., an increase in spleen and Dalton's lymphoma cells and a decrease in testes (Table 3) and blood (Table 2). Some amino acid precursors for glutathione synthesis, particularly glutamine, serve as important respiratory fuel for tumor cells (26) and tumor progression has been associated with an avid consumption of host glutamine by tumor cells causing a decrease in internal GSH concentration (32). The increase in GSH level in Dalton's lymphoma cells with tumor growth may also reflect increased uptake of essential amino acids from plasma with a consequent depletion of blood precursors for GSH synthesis, thereby reducing blood GSH concentration in tumor-bearing animals (Table 2). The GSH content of Dalton's lymphoma cells was also higher than that of splenocytes (the normal counterpart of Dalton's lymphoma cells) (Table 3). As GSH is known to play a role in detoxifying many reactive metabolites (33), its increased levels in Dalton's lymphoma cells and tissues of tumor-bearing mice could also represent a protective mechanism in response to various toxic radicals. 
Cisplatin treatment of mice caused a decrease of GSH in Dalton's lymphoma cells, kidney, bone marrow, spleen (Table 1) and blood (Table 2). The decrease in blood GSH levels in tumor-bearing mice and after cisplatin treatment may result in decreased antioxidant capacity. It has been observed that changes in glutathione levels in blood and development of various types of hematotoxicity in the host are inversely related in cisplatin-mediated chemotherapy (11). Evidence of low blood GSH has been reported in a variety of diseases including cancer (34). Similarly, the decrease in GSH levels in kidney, bone marrow and spleen after cisplatin treatment of the host may contribute to nephrotoxicity, mutagenicity and immune response, respectively. Indeed, when GSH levels were increased in the hosts, the nephrotoxic as well as mutagenic effects of cisplatin were found to be decreased (Khynriam D and Prasad SB, unpublished results).

In an attempt to understand the relationship between cisplatin-mediated cytotoxicity and decreased GSH levels in the hosts, particularly in Dalton's lymphoma cells, GST activity was assayed in Dalton's lymphoma cells. GST represents an integral part of the detoxification system and protects cells against oxidative and chemical-induced toxicity and stress by catalyzing the S-conjugation between the thiol group of GSH and the electrophilic moiety of toxic substrates including cisplatin (35). Cisplatin-GSH complexes have been proposed to be ejected from the cells in an ATP-dependent fashion by the glutathione S-conjugate (GS-X) export pump (36), thereby preventing the drug from reaching the critical DNA. GST activity decreased by $60-80 \%$ after cisplatin treatment. Thus, the decreased activity of GST as well as GSH concentration (Table 1) in Dalton's lymphoma cells after cisplatin treatment suggest the possibility of a reduced conjugation of GSH with cisplatin because it is known that cisplatin-GSH conjugates can be formed directly or be catalyzed by GST (36). This may suggest reduced elimination of the drug through export pumps and availability of more drug in tumor cells causing cytotoxic effects. Modulation of GST activity has been shown to affect the sensitivity of tumor cell lines to alkylating agents. Inhibition of GST by either ethacrynic acid or piriprost enhanced alkylator cytotoxicity to both rat and human cancer cell lines (37). Cisplatin also behaves like an alkylating agent, and therefore a similar modulation mechanism might be involved. Both GSH depletion by BSO and GST inhibition have increased the tumoricidal activity of melphalan, a proteolytic alkylating drug (38), supporting the present view of involvement of cisplatin-mediated decrease of GSH and inhibition of GST in its anticancer activity. This is further strengthened by the results of the experiments involving combined treatment with BSO, a GSH depleting agent, with cisplatin.

The treatment of mice with BSO caused maximal GSH depletion in Dalton's lymphoma cells at $8 \mathrm{~h}$ of treatment (Figure 2). For a better understanding of the significance of GSH modulation and cisplatin cytotoxicity, platinum uptake was determined in the Dalton's lymphoma cells treated with cisplatin alone or with BSO plus cisplatin. Platinum uptake by the tumor cells increased in the BSO plus cisplatin-treated groups, i.e., under decreased GSH conditions (Figure 3), supporting the view that GSH-platinum complexes are exported by pumps. The intracellular concentration of GSH could play an important role in determining cell sensitivity to drug-induced cytotoxicity. The therapeutic efficacy of cisplatin is limited because of the development of dose-dependent side effects in the host $(10,11)$ and acquired resistance in which increased GSH level and efflux of the drug are suggested to be participating factors (14). The use of a subtherapeutic dose ( $4 \mathrm{mg} / \mathrm{kg}$ body weight) of cisplatin in combination with vitamin $\mathrm{C}$ has 
been suggested to have better therapeutic efficacy than cisplatin alone, and decreased side effects in the host (39). Here, combined treatment with BSO and a subtherapeutic dose of cisplatin showed that, as compared to cisplatin alone, macrophage-Dalton's lymphoma cell interactions were significantly increased by about $37 \%$ in the BSO plus cisplatin-treated groups. This clearly suggests that the therapeutic response to a subtherapeutic dose of cisplatin could be enhanced when used in combination with BSO, which itself is a nontoxic agent. As the various side effects developed in the hosts are dose dependent, it may be suggested that, compared to higher doses of cisplatin, the modulation of GSH levels in combination with low doses of cisplatin should be very useful in decreasing the toxicity, with enhanced cytotoxicity in the host. This suggestion is supported by the results of host survival patterns under different treatment conditions. The percent increase in life span was about $53 \%$ in mice receiving a subtherapeutic dose of cisplatin alone and was doubled $(\sim 123 \%)$ after combination chemotherapy with BSO and a subtherapeutic dose of cisplatin (Figure 4, Table 4).

The enhanced drug uptake by Dalton's lymphoma cells under the conditions of reduced GSH levels and GST activity in Dalton's lymphoma cells should be an im- portant determining factor in the cytotoxic effects of cisplatin against murine ascites Dalton's lymphoma. Tumor cells are deficient in the ability to repair DNA after reaction with cisplatin (40). Although some recovery of GSH in Dalton's lymphoma cells was noted later at 72-96 $\mathrm{h}$ following cisplatin treatment (Table 1) along with elimination of the drug from the cells, a decrease in GSH levels and availability of more drug during the initial stage of treatment may be expected to give rise to a variety of metabolic dysfunctions directly or indirectly related to cisplatin cytotoxicity which may be partially repaired or retained within the Dalton's lymphoma cells, leading to tumor regression.

The data presented here suggest that changes in GSH levels in Dalton's lymphoma cells and other tissues during tumor growth and after cisplatin treatment could be an important factor contributing to tumor progression and cisplatin-mediated anticancer activity.

\section{Acknowledgments}

We thank the Head, Regional Sophisticated Instrumentation Center, North-Eastern Hill University, Shillong, for help with the platinum determinations.

\section{References}

1. Rosenberg B (1985). Fundamental studies with cisplatin. Cancer, 55: 2303-2316.

2. Prasad SB \& Giri A (1994). Antitumour effect of cisplatin against murine ascites Dalton's Iymphoma. Indian Journal of Experimental Biology, 32: 155-162.

3. Go RS \& Adjei AA (1999). Review of the comparative pharmacology and clinical activity of cisplatin and carboplatin. Journal of Clinical Oncology, 17: 409-422.

4. Chu G (1994). Cellular responses to cisplatin. Journal of Biological Chemistry, 269: 787-790.

5. Collins JL \& Kao M (1989). The anticancer drug cisplatin increases the naturally occurring cell-mediated lysis of tumor cells. Cancer Immunology, Immunotherapy, 29: 17-22.

6. Prasad SB \& Sodhi A (1981). Effect of cis-dichlorodiammineplatinum (II) on the agglutinability of tumor and normal cells with concanavalin
A and wheat germ agglutinin. Chemico-Biological Interactions, 36 355-367.

7. Prasad SB \& Giri A (1999). Cisplatin-induced changes in tissue calcium and potassium concentrations in tumour-bearing mice. Medical Science Research, 27: 459-462.

8. Prasad SB, Giri A, Khynriam D, Kharbangar A, Nicol BM \& Lotha C (1999). Cisplatin-mediated enzymatic changes in mice bearing ascites Dalton's lymphoma. Medical Science Research, 27: 723-730.

9. Kharbangar A, Khynriam D \& Prasad SB (2000). Effect of cisplatin on mitochondrial protein, glutathione, and succinate dehydrogenase in Dalton lymphoma-bearing mice. Cell Biology and Toxicology, 16: 363-373.

10. Krakoff IH (1979). Nephrotoxicity of cis-dichlorodiammineplatinum. Cancer Treatment Reports, 63: 1523-1525.

11. Khynriam D \& Prasad SB (2001). Hematotoxicity and blood glutathi- 
one levels after cisplatin treatment of tumor-bearing mice. Cell Biology and Toxicology, 17: 357-370.

12. Giri A, Khynriam D \& Prasad SB (1998). Vitamin C mediated protection on cisplatin-induced mutagenicity in mice. Mutation Research, 421: 139-148.

13. Prasad SB \& Khynriam D (2002). Mutagenicity and endogenous glutathione levels in tumor-bearing mice after cisplatin treatment. In: Khassanova L, Collery P, Maymard I, Khassanova Z \& Etienne JC (Editors), Metal lons in Biology and Medicine. Vol. 7. John Libbey Eurotext, Paris, France, 580-585.

14. Kartalou M \& Essigmann JM (2001). Mechanisms of resistance to cisplatin. Mutation Research, 478: 23-48.

15. Giri A, Khynriam D \& Prasad SB (1998). Use of vitamin C against cisplatin induced mutagenicity and nephrotoxicity. In: Sharan RN (Editor), Trends in Radiation and Cancer Biology. Forschungszentrum Jülich GmbH, Jülich, Germany, 166-176.

16. Bailey HH (1998). L-S,R-buthionine sulfoximine: historical development and clinical issues. Chemico-Biological Interactions, 111-112: 239-254.

17. Prasad SB, Khokhar AR \& Siddik ZH (1994). Potentiation by Lbuthionine sulfoximine (BSO) of cytotoxicity of platinum(IV) complexes in sensitive and resistant human ovarian carcinoma cells. In: Collery P, Poirier LA, Littlefield NA \& Etienne JC (Editors), Metal lons in Biology and Medicine. Vol. 3. John Libbey Eurotext, Paris, France, 365-370.

18. Arrick BA \& Nathan CF (1984). Glutathione metabolism as a determinant of therapeutic efficacy: a review. Cancer Research, 44: 42244232.

19. Wang W \& Ballatori N (1998). Endogenous glutathione conjugates: occurrence and biological functions. Pharmacological Reviews, 50: 335-355.

20. Suzuki CAM \& Cherian MG (1990). The interaction of cis-diamminedichloroplatinum with metallothionein and glutathione in rat liver and kidney. Toxicology, 64: 113-127.

21. Beutler E, Dunn O \& Kelly BM (1963). Improved method for the determination of blood glutathione. Journal of Laboratory and Clinical Medicine, 65: 882-888.

22. Sedlak J \& Lindsay RH (1968). Estimation of total, protein-bound and nonprotein sulfhydryl groups in tissues with Ellman's reagent. Analytical Biochemistry, 25: 192-205.

23. Habig WH, Pabot MJ \& Jarkoby WB (1974). Glutathione-S-transferase. The first enzymatic step in mercapturic acid formation. Journal of Biological Chemistry, 249: 7130-7139.

24. Lowry OH, Rosebrough NJ, Farr AL \& Randall RJ (1951). Protein measurement with the Folin phenol reagent. Journal of Biological Chemistry, 193: 265-275.

25. Dileepan KN, Lorsbach RB \& Stechschutte DJ (1993). Mast cell granules inhibit macrophage-mediated lysis of mastocytoma cells (P815) and nitric oxide production. Journal of Leukocyte Biology, 53: 446-453.

26. Estrela JM, Sternandez R, Terradez P, Asensi M, Puertes IR \& Vina J (1992). Regulation of glutathione metabolism in Ehrlich ascites tu- mour cells. Biochemical Journal, 286: 257-262.

27. Szatrowski TP \& Nathan CF (1991). Production of large amounts of hydrogen peroxide by human tumor cells. Cancer Research, 51: 794-798.

28. Toyokuni S, Okamoto K, Yodoi J \& Hiai H (1995). Persistent oxidative stress in cancer. FEBS Letters, 358: 1-3.

29. Estrela JM, Obrador E, Navarro J, Lasso De La Vega MC \& Pellicer JA (1995). Elimination of Ehrlich tumours by ATP-induced growth inhibition, glutathione depletion and X-rays. Nature Medicine, 1: 8488.

30. Shaw JP \& Chou IN (1986). Elevation of intracellular glutathione content associated with mitogenic stimulation of quiescent fibroblasts. Journal of Cellular Physiology, 129: 193-198.

31. Terradez P, Asensi M, Lasso De La Vega MC, Puertes IR, Vina J \& Estrela JM (1993). Depletion of tumour glutathione in vivo by buthionine sulfoximine: modulation by the rate of cellular proliferation and inhibition of cancer growth. Biochemical Journal, 292: 477483.

32. Amores-Sanchez MI \& Medina MA (1999). Glutamine as a precursor of glutathione and oxidative stress. Molecular Genetics and Metabolism, 67: 100-105.

33. Hinchman CA \& Ballotori N (1994). Glutathione conjugation and conversion to mercapturic acid can occur as an intrahepatic process. Journal of Toxicology and Environmental Health, 41: 387-409.

34. DellaRovere F, Granata A, Saija A, Broccio M, Tomaino A, Zirilli A, De Caridi G \& Broccio G (2000). -SH groups and glutathione in cancer patient's blood. Anticancer Research, 20: 1595-1598.

35. Welters MJP, Fichtinger-Schepman AMJ, Baan RA, Flens MJ, Scheper RJ \& Braakhuis BJM (1998). Role of glutathione, glutathione S-transferases and multidrug resistance-related proteins in cisplatin sensitivity of head and neck cancer cell lines. British Journal of Cancer, 77: 556-561.

36. Ishikawa T \& Ali-Osman F (1993). Glutathione-associated cisdiamminedichloroplatinum(II) metabolism and ATP-dependent efflux from leukemia cells: molecular characterization of glutathione platinum complex and its biological significance. Journal of Biological Chemistry, 268: 20116-20125.

37. Hansson J, Berhane K, Castro VM, Jungnelius U, Mannervik B \& Ringborg U (1991). Sensitization to human melanoma cells to the cytotoxic effect of melphalan by the glutathione transferase inhibitor, ethacrynic acid. Cancer Research, 51: 94-98.

38. Canada AT, Herman L, Kidd K, Robertson C \& Trump D (1993). Glutathione depletion increases the cytotoxicity of melphalan to the androgen-sensitive prostate cancer cell line, PC-3. Cancer Chemotherapy and Pharmacology, 32: 73-77.

39. Prasad SB, Giri A \& Arjun J (1992). Use of subtherapeutical dose of cisplatin and vitamin C against murine ascites Dalton's lymphoma. Polish Journal of Pharmacology and Pharmacy, 44: 383-391.

40. Szymkowski DE, Yarema K, Essigmann JM, Lippard SJ \& Wood RD (1992). An intrastrand d(GpG) platinum crosslink in duplex M13 DNA is refractory to repair by human cell extracts. Proceedings of the National Academy of Sciences, USA, 89: 10772-10776. 